\title{
Effect of Non-Performing Loans on the Profitability of Universal Banks: A Time Series Analysis of the Ghanaian Banking Industry
}

\author{
Matthew Korankye ${ }^{1 *} \quad$ Dzah Bright $^{2} \quad$ Moses Dunyoh $^{3}$ \\ 1.School of Graduate Studies, University of Kwame Nkrumah, Kumasi \\ 2.Best Brain Consult, Independent Researcher, Tema \\ 3.Lecturer, Data Link Institute of Business and Technology, Tema
}

\begin{abstract}
The primary purpose of this research is to examine the effect of Non-Performing Loans (NPLs) on the profitability of universal banks in Ghana. The study is focused on the effect of non-performing loans on return on assets and return on equity of universal banks in Ghana. The study uses quarterly time series data collected by Bank of Ghana on all universal banks operating in the banking sector for the period 2007 - 2018. The multiple regression technique is used to analyse the models developed. The study reveals that non-performing loans have a significant negative effect on return on equity of universal banks in Ghana. The study also reveals a significant negative relationship between non-performing loans ratio and return on asset. The study recommends an improvement in the profitability of universal banks by reducing non-performing loans in individual banks. Universal banks must improve their loan monitoring strategies and manage their loan risk exposure to customers. The study recommends an improvement of the regulatory system of the central bank. Appropriate guidelines must be instituted by the central bank to prevent universal banks from advancing loans to customers with high credit risk.
\end{abstract}

Keywords: non-performing loans, banks profitability, time series, universal banks

DOI: $10.7176 / \mathrm{RJFA} / 13-2-03$

Publication date: January $31^{\text {st }} 2022$

\section{Introduction}

Banks as part of the financial system enables lenders, investors, and borrowers to exchange funds through accepting deposits and granting loans to customers. This crucial role banks play improves the economic conditions of nations in different ways. Therefore, the main operation of the bank is lending and the bulk of the bank's assets are cumulated in loans (Kipyego \& Wandera, 2013; Richard, 2016). According to the research by Curak, Pepur, and Poposki (2013), loan interest provides substantial contribution to the income of commercial banks. Rawlin, Shwetha \& Sharan and Pradeep (2012) indicate that, majority of universal banks earn their income through interest charges on loans, this makes loans form majority of a bank's assets.

Though bank facilities and loans are mutually beneficial, they suffer the risk of loss arising from nonperforming (Yurttadu, Celiktas \& Celiktas 2019; Talata, 2015; Klein, 2013). According to Eston, Willy and Agnes (2016), the core revenue generating function of banks is lending nevertheless it also exposes the banks to default risk on the part of clients leading to non-performing loans. A high credit risk exposure faced by banks lead to a high tendency of loans going bad (Jimenez \& Saurina, 2015). Unfortunately, the detrimental effect of nonperforming loans on the performance of banks and the entire financial system has made the subject of nonperforming loans a universal one. The phenomenon has gained significant attention over the last decades as a result of the challenges it poses to banks (Kipyego \& Wandera, 2013; Joseph et al., 2012).

Non-Performing Loan (NPLs) is a portion of bank's financial resources which the bank is no more receiving neither interest nor instalment payments as initially agreed (Haneef et al., 2012). NPLs therefore impair the banks' capability of generating revenue from its main activity of giving out loan facilities to customers. Kolapo, Ayeni, and Oke (2012) argued that customers' deposits are offset by the margins from credit facilities created as loans and if such resources fail to generate the appropriate revenue, the banks' ability to honour repayment of the deposit amount on time would be in question. Ultimately unrecoverable debts are written off from the books of the banks as non-performing loans. When the amount of non-performing loans of banks continue to surge, customers lose faith and confidence in the ability of the banks to manage their deposits properly which eventually results in the failure of the bank.

Sobarsyah et al. (2020) find that the effect of NPLs is not only detrimental to the balance sheet of banks, threating it performance but affects the very sustainability of the banking sector. Mwangi (2012) found an inverse relationship between NPLs and bank profitability and as the value of NPLs increase, bank profitability declines. Alshatti (2015) noted that downturn in the value of the loan records was a major cause of financial turmoil in banks that would eventually affect the country's entire financial system. Previous studies (Ng'etich \& Wanjau, 2016; Beck, Jakubik \& Piloiu, 2013; Afriyie \& Akotey, 2013) and the events recorded worldwide indicate that cumulative bad loans play a key role in the insolvencies of financial institutions and evidence of the universal financial failure and the consequent recession has significantly afflicted not only banks and the financial industry but the global economy. The situation with rising NPLs is that, it destroys value, damage the confidence of 
investors and drive away deserving loan borrowers out of the financial system (Mwangi, 2012; Nyarko, 2018; Afriyie \& Akotey, 2013; Yurttadu, Celiktas \& Celiktas 2019).

There is a number of research writing in economics and finance to show that the inability to successfully manage credit risk leading to NPLs is the key cause of banking sector crises which to a large extent led to huge economic fallout and failure of Lehman Brothers and other banks (Merill Lynch, HBOS, Royal Bank of Scotland, Bradford and Bingley) causing a global economic financial crisis (Kjosevski, Petkovski \& Naumovska, 2019; Partovi \& Matousek, 2018). Ghana is no exceptions as it has also been hit by NPLs which has led to the recent restructuring of the Ghanaian banking sectors. According to Bank of Ghana (BoG) report (2018), the stock of NPLs of the banking industry has increased by 1.53 billion in just one year. As at 2019, 9 universal banks, 347 microfinance companies, 39 micro credit companies'/money lenders, 15 savings and loans companies, 8 finance houses companies, and 2 non-bank financial institution has failed due to high NPLs in the banking sector. The challenges non-performing loans pose to the Ghanaian financial sector is very critical to the financial performance and the viability of the sector and is an issue that is of importance to bank boards, management, policy makers and academics

Research over the years have suggested that many banks in Ghana are making huge losses due to the problem of non-performing loans on their books and this is negatively affecting not only the banking industry but other industries. (Alshatti, 2015; Kipyego \& Wandera, 2013; Richard, 2016; Sobarsyah et al. 2020). Increasing NPLs is an important and recurrent issue that management of banks have to face in the course of doing business which is not just a problem of the Ghanaian banking sector but a worldwide challenge (Asantey \& Tengey 2014; Eston, Willy, \& Agnes, 2016; Pop, Cepoi, \& Anghel, 2018). Many scholars have investigated and written papers on the relationship of NPLs and financial performance of banks focusing on individual banks or selected banks in the sector, but limited work has been done to explore the relationship between NPLs and bank performance at the industry level. The research seeks to fill the literature gap by investigating extensively into how NPLs can affect the profitability of universal banks in Ghana at the industry level. The purpose of this study is therefore substantially important not only for bank management but also for policy makers and academicians.

The following sections discuss the literature review, methodology, data analysis and discussions, and conclusion the study.

\section{Literature Review}

\subsection{Conceptual Framework}

2.1.1 Non - Performing Loans (NPLs)

Typically, a loan is a contractual agreement between the creditor (bank) and the borrower (customer) where loanable funds are provided to the customer with a promise to pay back according to the terms of the contractual agreement, whether by a lump sum payment or payment in instalment over the term period (Kipyego \& Wandera, 2013). Processing fees, commissions, monitoring fees and interest charges are paid as finance costs in addition to the principal amount that is being borrowed, per the loan contract. These additional charges based on the credit facility covenants makes up the interest revenue of the lender/creditor (bank). According to Kolapo, Ayeni and Oke (2012), interest income is the primary source of revenue for commercial banks. A loan is therefore considered as 'performing' when both the principal and interest in respect to the credit facility is paid on time, as stipulated in the loan agreement (Karim, Chan, \& Hassan, 2010). This goes to show that before a loan can be declared as performing, it has to meet the minimum criteria of an up-to-date payment of both the amount borrowed and the interest that has been accrued in accordance with the terms as stipulated in the loan agreement between the parties. According to the Bank of Ghana (BoG), when payment of interest and principal of loans are up to date, they are classified as performing loans, and overdrafts are classified as performing when there are frequent undertakings in the bank accounts without any sign of debt build-up (BoG, 2018). It can consequently be inferred that a healthy asset portfolio is one within which loans are performing and payment on both interest and principal are timely.

According to Kolapo, Ayeni and Oke (2012), loans that are in arrears for both principal and interest for a period contrary to contractual terms stated in the loan covenant are categorized as non-performing loans. There are diverse descriptions in literature with regard to non-performing loans (Chimkono, Muturi and Njeru, 2016; Asantey and Tengey, 2014; Nyarko, 2018). Research has shown that both qualitative and quantitative approaches can be used in assessing whether or not a loan is performing or non-performing (Vithessonthi, 2016). Quantitative approach examines number of days for which payment of both principal and interest of the credit facility is outstanding, whereas the qualitative approach relies on other information such as customer's financial status and management judgement about future payments. Partovi and Matousek (2018) classify loans due or no longer accruing interest that are ninety days or more past as non-performing. Fofack (2015), in line with Partovi and Matousek (2018) points to the fact that non-performing loans are loans that do not produce revenue for a reasonably long period of time, that is both the interest and principal on these loans remain unpaid for a minimum of ninety days. The Bank of Ghana also classifies loans as non-performing when they are overdue for ninety days or more (Baasi, 2018). 
Bank loans are classified as non-performing when the loans cease to generate income for the bank. These loans are financial assets from which banks expect to generate revenue (interest income) but no longer receive interest and principal as the terms of the loan's agreement prescribes (Bofondi and Ropele, 2011). Non-performing loans do not only negatively affect the financial performance of the bank, but they also increase the financial, credit and liquidity risk of the bank (Chege, and Bichanga, 2016). Therefore, non-performing loans are viewed as a typical by-product of a financial crisis which is incidental to the lending process, leading to an involuntary default or planned default by borrowers and has the potential of deepening the severity and duration of financial crisis that the lending institution has to go through (Epure and Lafuente, 2012).This is because non-performing loans can bring down investor confidence in the banking system, pile up unproductive economic resources and impede the resource allocation process. Increasing non-performing loans can impede economic recovery of banks which has undergone restructuring or mergers as the case has been recently in Ghana, by shrinking operating margin and eroding the capital base of the banks. In addition, non-performing loans are as a result of unwillingness of borrowers to pay back both interest and principal of their loans, which, if left unresolved, pushes good borrowers out of the financial market, hence NPLs could act as a contagious financial malaise towards the financial sector. (Kargi, 2011; Kithinji, 2010; Arko, 2012).

2.1.2 Causes of Non - Performing Loans

Non-performing loans is an issue that has plagued the banking sector in many jurisdictions and has led to the failure of most banking institutions across so many countries (Capario and Klingebiel (1996) Bloem and Gorter, 2011; Rawlin et al, 2012; Kipyego \& Wandera, 201). Esteban (2012) argues that most bank failures are caused by non-perfoming loans. NPLs has been an area that has affected more than half of banks loans portfolio. For example, Abiola, \& Olausi (2014) indicate that non-performing loans represents $75 \%$ of total loan assets of commercial banks in Nigeria. According to the Bank of Ghana report in 2018, the stock of NPLs increase from GHS 7.1billion as at end of April 2017 to GHC8.63billion in April 2018, representing about a fifth of the banking industry's loan portfolio which was impaired between the period April 2017 and April 2018 (Bank of Ghana, 2018). Over the years the issue of non-performing loans has become a research subject, to understand and find possible causes of NPLs and many studies have pointed out some causes of NPLs according to their findings:

- Insider Lending

According to Awoyemi (2014), the single largest contributor to NPLs in most failed commercial banks is the issue of insider lending also better-known as related party lending. Chege and Bichanga (2016) argue that in Kenya, related party lending or insider lending accounts form at least half of banks loans and lead to their eventual failure. Chege and Bichanga point out that loans through this medium make up a substantial portion of the total bad debt on the books of the banks when they collapsed. In furtherance of the earlier point, major banks such as Pan African Bank, Trade Bank and Continental Bank have all been involved in substantial insider loans, often to directors, politicians and other parties closely related to the banking institution without proper collateral or due process (Chege and Bichanga, 2016). In Ghana, several banks have also had the issue of related party transactions which the Bank of Ghana point out as part of the reasons for their collapse and the revocation of their licences. According to the Bank of Ghana (2018), UniBank has given out GHS 5.36 billion to shareholders and related parties constituting $75 \%$ of the total asset of the bank without due process and Royal Bank has an amount GHS 161.92 million given to shareholders and related parties. Chege and Bichanga (2016) posits that the threat emanating from insider lending is that, majority of these loans eventually go bad and are written off because they are invested in risky ventures such as the construction of real estate and others; shopping malls and hotels that are unable to produce short-term returns that result in an imprudent mismatch of the assets and liabilities of the bank.

\section{- $\quad$ Poor Credit Culture}

Poor credit culture is another major cause of NPLs (Abdullahi, 2013; Ekanayake and Azeez, 2015). Studies shows that in most financial institutions, poor management of the credit process contributes to the issue of NPLs. Chimkono, Muturi, and Njeru (2016), and Eston, Willy \& Agnes, (2016), note that the credit culture of many banks is very poor and underline by moral hazards and adverse selection. Credit appraisal, credit monitoring and poor control practices also contribute to the growing non-performing loans in the banking sector. Credit culture as practiced in most banking institutions has not contributed in any way to prevent the spiralling nature of NPLs in Ghana, proof of which is the 2017-2019 banking crisis in Ghana (Bank of Ghana, 2018). Abdullahi (2013) argues that in the area of credit control, NPLs occur when bank accounts are overdrawn without any limitation to determine who can overdraw on an account, or how much overdraft can be withdrawn from the account which for some time has been actively running in excess of the reasonable operating limit. Bank of Ghana (2018) reports that an amount of GHS 3.7 billion given out as loans by UniBank Ltd did not follow the normal credit delivery process and this amount (GHS 3.7 billion) was later declared non-performing.

\section{- Interest Rate}

The high cost at which businesses mobilise funds is also another cause of NPLs in the banking sector. The interest rate is the price paid by a lender for the use of assets expressed as a proportion of the principal. The cost of borrowing in many countries according to Bloem and Gorter (2011) can lead to loan default when it is time for 
payment of both principal and interest. The core moral hazard on the part of both financial institutions and their creditors is high interest rate charges. Ikram, Su \& Sadiq (2016) argue that when interest on loans is high, it is difficult for borrowers to repay the interest and the principal when the loan is due. Kamran et al (2016) posit that NPLs in developed countries are low compared to developing countries as a result of difference in the rate of interest paid for loans. For example, the real interest rate in developed countries such as the United States is $0.25 \%$, United Kingdom is $0.1 \%$, Australia is $0.25 \%$ as compared to interest rate in developing economies; Zimbabwe has an interest rate of $35 \%$, Nigeria is $12.5 \%$, Ghana is $14.50 \%$, and Yemen is $27 \%$ (Trading Economics, 2020). Khalid (2012) corroborate the point that lending at high interest rates to borrowers in the high-risk segment of the credit system is a major factor leading to bank failures.

- Inflation Rate

Klein (2013) argues that inflation is also a major cause of non-performing loans. Klein points to the fact that the overall prices of goods and services can determine whether or not an individual or business can pay back their loan. High inflation affects business performance in a volatile manner and can result in a high cost of doing business (Klein, 2013). The high cost of doing business translates into defaulting on loan payment. Conversely, high inflation typically includes a high degree of uncertainty in interest rate levels because interest rates are normally adjusted for inflation and as a result most interest rates are variable in order to account for inflation. Inflation increases both adverse selection and adverse incentives to take risks for creditors, and hence the probability of default on loans (Kwambai \& Era, 2013).

2.1.3 Bank Profitability

Profitability is an important measure in banking operations. Profitability is a relative metric that relates to an organization's ability to gain profit (Tulsian, 2014). There is significant amount of literature on measurement of profitability both in academics and industry as the best way to assess the efficient and effective management of banks resources. Tulsian (2014) describes profit as the variance over a period of time between total sales and total expense. By making more revenue than what they pay in expenses, a bank can produce profit, and most banks profit is generated from interest income received on their assets and fees paid for their services (Durafe and Singh, 2016). Profitability is a crucial metric that measures a company's overall performance and illustrates how efficiently the company has used its capital (Kwambai \& Era, 2013). Most investors in the financial space are interested in how well a bank is performing before considering any potential investment which points out that a high stock price alone cannot be used as a good indicator to determine whether or not investors will invest in the bank. Bank profitability is measured on the basis of return on equity (ROE) and return on asset (ROA), which are part of the commonly used measures for profitability within the banking sector. According to Mohammed (2012), it is imperative that key financial indicators such as ROA and ROE are calculated and interpreted from the data that the bank's financial statements provide to further assess whether the bank is performing.

- $\quad$ Return on Assets (ROA)

ROA is the profitability ratio that measures the profitability of a business in relation to its assets or the amount of revenue the assets of the bank generates (Greenidge and Grosvenor, 2010). The return on assets is regarded to be a significant measure of an entity's profitability in relation to its total assets. The ROA provides experts with the concept of how effective management is investing the entity's resources for the purpose of harvesting revenue. The percentage ratio is shown and determined by dividing the annual income or net earnings by the total assets. ROA shows the earnings generated from the invested assets. The preferred method of using ROA for a comparable calculation is to compare the previous ROA of the same or similar business. Both debt and equity represent the company's assets, and both asset types are used to fund the company's operations. Investors can understand whether the company turns its assets into operating earnings efficiently or not by looking at the ROA ratio. Higher ROA implies better results as it illustrates that the business raises more or spends less. ROA is the most widely used profitability measure that has appeared in numerous studies, such as Trujillo-Ponce (2013).

- $\quad$ Return on Equity (ROE)

Return on Equity (Net Profit divided by Equity) shows that management is effectively using its assets to create profit in order to measure the efficiency of a bank in generating future profits (Greenidge and Grosvenor, 2010). ROE is somewhat similar to ROA and is commonly used to reflect profitability alone or with ROA and net interest margin (NIM) in several studies. It is the rate of return or net income in the form of a percentage of the interest of the shareholder. The ROE may also be regarded as a metric of profitability since it indicates how much gain the business earns from the amount of money invested by shareholders. For the entire fiscal year, net income is included (before dividend distribution to the shareholder but after distributions on preference shares) and preference shares are excluded in the shareholder's interest. The ROE is most useful when comparing the profitability of two or more firms within the same sector. ROE also offers an indicator of financial success because it reveals whether the corporation receives profit without the business being infused with new equity capital. On the other hand, ROE also acts as a growth rate speed limit, which is used to estimate the potential growth by many managers. 


\subsection{Theoretical Review}

\subsubsection{Adverse Selection Theory}

The adverse selection theory postulates that an unequal information in the marketplace distorts the market and leads to market failure. Adverse selection defines situations under which a buyer or seller has more knowledge than the other party, explicitly regarding risk factors in relation to a particular company or transaction undertaking (Khemraj and Pasha, 2012). Klein (2013) argues that lenders (banks) are sometimes not transparent with their loan pricing policies and borrowers also fail to disclose the actual purpose for which they seek the loan, their actual risk profile. In cases where both the lender and the borrower are knowledgeable to different levels, asymmetric information is created as opposed to when both sellers and buyers have the similar amount of information to enter into a loan transaction (Karim, Chan, \& Hassan, 2010). The theory of adverse selection rest on the basis that lenders are unable to differentiate between creditors with various degrees of risk and that credit contracts are constrained. (Karim, Chan, \& Hassan, 2010). Asymmetric information, also called information failure from the part of the borrower, happens when the borrower has greater material knowledge than the lender and this makes it difficult to categorise borrowers according to their risk profiles (Klein, 2013). A rise in loan interest rates, for instance, would disproportionately impact low-risk borrowers and could cause them to drop out of a pool of loan applications. However, in the face of competition and flexible or low interest rates, excess demand in the credit market may continue. Commercial banks will have a dilemma: whether to raise interest rates and limit the number of applicants, or whether to lower rates and have more applicants, some of whom will fail to repay their loans. Therefore, in line with this adverse selection theory, it will be difficult to rely on interest rates to guarantee that all loan applicants can afford credit because interest rate is limited in determining who is appropriately suited for the loan, as it has no information on the borrowers. According to the adverse selection theory, sharing information decreases adverse selection by enhancing banks' data on prospective borrowers (Klein, 2013). Lenders can reduce adverse selection issues through improved screening systems, a process that lenders have been continuously improving. The screening process allows banks to gather enough information as possible from their loan applicants for a sound decision as to whether or not they are fit to be given a loan and if they will have the ability to pay back the loan with interest on time. In order to help in the screening process, credit scoring has become much more sophisticated over time, but most developing countries like Ghana often lack credit bureaus and, in many instances, unique identification numbers for residents to help monitor their credit history (Boahene, Dasah and Agyei 2012). Credit bureaus are playing a vital role in levelling information asymmetries among lenders and borrowers, nevertheless they are only able to provide information that lenders still need to interpret to determine whether to authorize the loans and under what conditions. Bloem and Gorter (2011) argue that ordinarily, individual banking institutions have private information about their loan applicants but if banks were to share information about their clients' credit worthiness with other banks, the quality of information on credit applicant will help to minimize information asymmetry between lenders and borrowers. Loans will be extended at a lower risk to borrowers with a lower credit risk reducing the likelihood of non-performing loans (Bloem and Gorter, 2011). The adverse selection postulates a positive relationship between credit risk and NPLs which in turn negatively affects profitability of universal banks.

\subsection{Empirical Review}

Empirical literature review focuses on examining related works that have been carried out by other researchers by analysing their finding and drawing on the knowledge of their findings. It basically tells a story of what has been done elsewhere and in similar context regarding the topic under consideration and their respective outcomes. The review of related work helps to position the findings of the study by making appropriate comparison and contrasting.

To begin with, Chege and Bichanga (2016) conduct a research on non-performing loans and financial performance on commercial banks in Kenya. The study shows that non-performing loans have a statistically significant effect on financial performance measured using ROA as a proxy. Islam \& Nishiyam (2019) find evidence which agrees with the finding above in a study on non-performing loans of commercial banks in South Asian countries. The researchers empirically analyse the bank-specific, industry-specific and macroeconomicspecific determinants of non-performing bank loans in South Asian countries using the GMM estimator. The study finds that Stiglitz and Weiss (1981) adverse selection hypothesis are still effective in South Asian countries.

In another study, Okoh, Inim \& Idachaba, (2019) research into the effect of NPLs on the financial performance of Nigerian commercial banks. The study employs the multiple regression technique on the data obtain. The findings of the study show that non-performing loans affect Return on Asset (ROA) of the bank negatively and it is statistically significant. The researchers indicate that, the increase in NPLs of commercial banks in Nigeria reduces profitability. Other researchers also find a negative relationship between non-performing loans and banks' financial performance (Greenidge and Grosvenor, 2010; Mwangi,2012; Durafe and Singh, 2016).

Also, Linh-Doa, Xuan-Ngoa, \& Anh-Phunga (2020) conduct a study on the effect of non-performing loans on commercial banks' profitability in Vietnam. The research collects data on the annual gross domestic product 
(GDP) growth rate, profitability (ROA), the loan-to-deposit ratio (LDR), the non-performing loan ratio (NPLR) and the size of the bank (BANKSIZE). The study suggests that there is an inverse relationship between nonperforming loans and commercial banks' return on assets (ROA) in Vietnam.

Mwangi, (2014) examines the effect of nonperforming loans on the financial performance of commercial banks in Kenya. The study collects data on Return on assets (ROA) and NPL from the banks. The study adopts a simple linear regression analysis. The results from the study confirm high level of NPLs resulting in a very low ROA. Congruent with Mwangi's finding, Ekanayake and Azeez (2015) examine non-performing loans in Sri Lanka's licensed commercial banks. The study results show that non-performing loans appear to rise with the efficiency of banks declining. A positive association between loan to asset ratio and non-performing loans is found in the analysis. They also find that banks' profitability is adversely affected by NPLs.

On the Ghanaian front, Baasi (2018) investigates the effects of non-performing loans on the profitability of commercial banks on the Ghana Stock Exchange. The study adopts the panel regression analysis. The findings of the study point out that non-performing loan negatively affect profitability. Similarly, Afriyie \& Akotey (2013) examine NPLs of rural banks in the Brong Ahafo Region of Ghana. The findings of the study after a panel data analysis reveal that NPL has an effect on profitability. The study finds an increase in the level of profits in rural banks despite their high NPLs. The finding reveals that MFIs transfer the risk of loan impairment to other customers in the form of high interests. In a study of causes and effects of NPLs on MFIs' operations in Ghana, Arko (2012) finds that NPLs are affected by lending decisions. The finding also reveals high level of NPL in MFIs.

\subsection{Conceptual Framework}

Based on the above review, the following conceptual framework is adopted

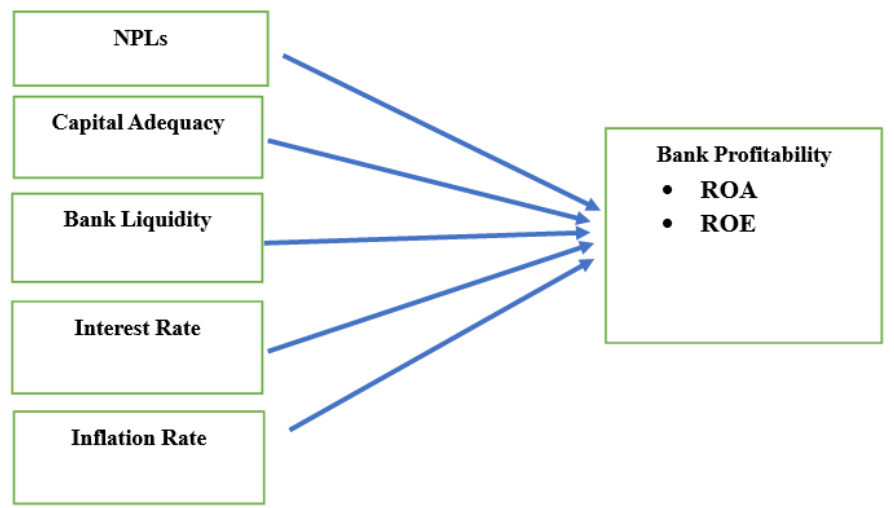

Figure 2.1: Conceptual Framework

Source: Researchers construct, 2020.

\section{Methodology}

\subsection{Research Design}

To achieve the purpose of the research, the descriptive research design is used to obtain an in-depth insight into the relationship between the independent variables (non-performing loan ratio, capital adequacy ratio, liquidity ratio, interest rate, inflation rate) and dependent variables (return on asset, return on equity) under consideration. The descriptive research design is useful in providing detail contextual analysis to gain an understanding of the relationship between NPLs and profitability of universal banks. The descriptive research design helps to identify and describe trends and variation in a data and aimed at identifying causal effects.

\subsection{Data Source}

The study uses secondary data that have been collected by the Bank of Ghana on commercial banks in Ghana over the years. The data are quarterly time series data collected over a number of years from the entire banking industry. The variables; non-performing loans, capital adequacy, liquidity, return on equity, return on asset are collected from the financial soundness indicators. Inflation and interest rate are collected from the economic indicators. The quarterly (Q1-Q4) data covers a period of 11 years from 2007 to 2018.

\subsection{Model Specification}

The following econometric models were estimated;

\section{Model 1}

ROA it $=\beta 0+\beta 1($ NPLR $)$ it $+\beta 2($ CAR $)$ it $+\beta 3($ LR $)$ it $+\beta 4($ IR $)$ it $+\beta 5($ IFR $)$ it $+\varepsilon$ it $\ldots . .1$

Where;

$\mathrm{ROA}=$ Return on Assets 
NPLR $=$ Non-Performing Loan Ratio

$\mathrm{CAR}=$ Capital Adequacy Ratio

$\mathrm{LR}=$ Liquidity Ratio

$\mathrm{IR}=$ Interest Rate

IFR $=$ Inflation Rate

$\beta 0-\beta 5=$ Estimated coefficient of the independent variables

$\varepsilon \mathrm{t}=$ Residual for the long run equation (error term)

it $=2007,2008,2009,2010$ 2018

Model 2

$\mathrm{ROE}$ it $=\beta 0+\beta 1(\mathrm{NPLR})$ it $+\beta 2(\mathrm{CA})$ it $+\beta 3(\mathrm{BL})$ it $+\beta 4$ (IR) it $+\beta 5(\mathrm{IFR})$ it $+\varepsilon$ it $\ldots \ldots \ldots 2$

Where;

$\mathrm{ROE}=$ Return on Equity

NPLR $=$ Non-Performing Loan Ratio

$\mathrm{CAR}=$ Capital Adequacy Ratio

$\mathrm{LR}=$ Liquidity Ratio

$\mathrm{IR}=$ Interest Rate

IFR $=$ Inflation Rate

$\beta 0-\beta 5=$ Estimated coefficient of the independent variables

$\varepsilon \mathrm{t}=$ Residual for the long run equation (error term)

it $=2007,2008,2009,2010 \ldots \ldots .2018$

Table 3.1: Measurement of Variables

\begin{tabular}{|c|c|c|c|}
\hline Description & Symbol & Measurement & Expected Sign \\
\hline \multicolumn{4}{|l|}{ Dependent Variables } \\
\hline Return on Equity & ROE & Percentage of return on equity at time $t$ & \\
\hline Return on Asset & $\mathrm{ROA}$ & Percentage of return on asset at time $t$. & \\
\hline \multicolumn{4}{|l|}{ Independent Variables } \\
\hline Non-performing loan Ratio & NPLR & Percentage of Non-performing loans at time $t$ & Negative \\
\hline Capital Adequacy Ratio & CAR & Percentage of Capital Adequacy ratio at time $t$ & Positive \\
\hline Liquidity Ratio & LR & Core Liquid assets to total assets at time $\mathrm{t}$ & Negative \\
\hline Interest Rate & IR & Percentage of interest rate at time $t$ & Negative \\
\hline Inflation Rate & IFR & Percentage of inflation at time $\mathrm{t}$ & Negative \\
\hline
\end{tabular}

Source: Researcher construct, 2020

\subsection{Data Analysis}

The data collected from the bank of Ghana database are tested for unit root and multicollinearity of the variables. The data are summarized and classified to facilitate further analysis to be performed on the data. The STATA 15 statistical package is used and descriptive statistics analysis is performed.

\section{Data Analysis and Results}

\subsection{Descriptive Statistics}

The descriptive analysis presents the mean, standard deviation, the maximum and minimum values of the variables in Table 4.1.

Return of equity (ROE) has a mean of 22.95, a maximum value of 34.01 and a minimum value of 11.39 with a standard deviation of 5.19. The finding reveals that universal banks in the banking industry return averagely $23 \%$ of the equity investment that they receive from equity holders. The high standard deviation indicates that there is a high variation in profitability (ROE) across the banks. The study reveals that the average return on asset (ROA) for universal banks is 4.27 with a standard deviation of 1.12. The minimum return on asset among the universal banks is as low as 2.61 and as high as 6.85. The average return on asset (ROA) is very low. The universal banks in Ghana return averagely about $1.12 \%$ on their assets which is evident that the banking sector is not effectively utilising their assets to generate interest income. It is evident that universal banks are not generating enough profit from their assets. The mismanagement of their loan assets is causing a lot of them to go bad. Bank of Ghana after an Asset Quality Review (AQR) in 2016 reveals a severe deterioration in the asset quality of universal banks in the sector which has resulted in toxic balance sheets (BoG, 2018).

According to Table 4.1, the mean non-performing loan ratio (NPLR) is 14.29 with a maximum value of 22.58 and a minimum value of 6.14 . This indicates that averagely $14 \%$ of the loans of universal banks are impaired and, as high as $23 \%$ for some banks in the banking industry. According to PwC (2018), over a period of one year (20172018), the stock of NPLs increase by GHS 1.53 billion from GHS 7.1 billion as at end of April 2017 to GHS 8.63 billion in April 2018. This phenomenon supports the Bank of Ghana position, after the comprehensive Asset Quality Review, that asset quality remains a major concern to universals banks. Non-performing loans remain high 
and high NPLs is a key factor in the collapse of some of the banks (UT Bank, UniBank, Royal Bank) in Ghana around 2017-2018 (BoG, 2018). In line with the result, it is apparent that as of 31 May 2018, over 89 percent of UniBank's loan book of GH 3.74 billion was listed as non-performing (BoG, 2018).

Table 4.1: Descriptive Statistics of dependent, independent and control variables.

\begin{tabular}{llllll}
\hline Variable & Obs & Mean & Std. Dev. & Min & Max \\
\hline ROE & 48 & 22.95958 & 5.193121 & 11.39 & 34.01 \\
ROA & 48 & 4.273542 & 1.124848 & 2.61 & 6.85 \\
NPLR & 48 & 14.29646 & 4.595584 & 6.14 & 22.58 \\
CAR & 48 & 17.17333 & 1.791782 & 13.77 & 20.54 \\
LR & 48 & 32.19063 & 2.184738 & 26.58 & 35.29 \\
IR & 48 & 17.69271 & 4.170642 & 12.5 & 26 \\
IFR & 48 & 13.29063 & 3.798563 & 8.4 & 20.74 \\
\hline
\end{tabular}

Source: Researchers construct, 2020 (Financial Soundness Indicators 2007 - 2018)

There is a general upward trend in NPLR over the period from 2007 to 2018 as presented by figure 4.1 even though NPLR has fluctuated over the period. The overall analysis for the period of 12 years shows an increment in the NPLR in the banking industry over the period. The ratio of impairment of the loan portfolio in the banking industry has been on the rise from 2007 through to 2018 which was captured by the trendline. NPLR of the banking sector over the period is lowest in $2007 \mathrm{q} 3$ at $6.14 \%$, then increase to $18.49 \%$ in $2010 \mathrm{q} 1$ and from 2010 , NPLR further falls to 10.98 in $2014 \mathrm{q} 4$ before rising again to 22.58 in $2018 \mathrm{q} 1$. The highest values of NPLR are recorded between 2017 - 2018, and in 2018q1, non-performing loans ratio (NPLR) is at its highest at a value of $22.8 \%$. This further confirms the banking clean-up exercise which the Bank of Ghana carried out in the same period (20172018) because of challenges in the banking sector at that time.

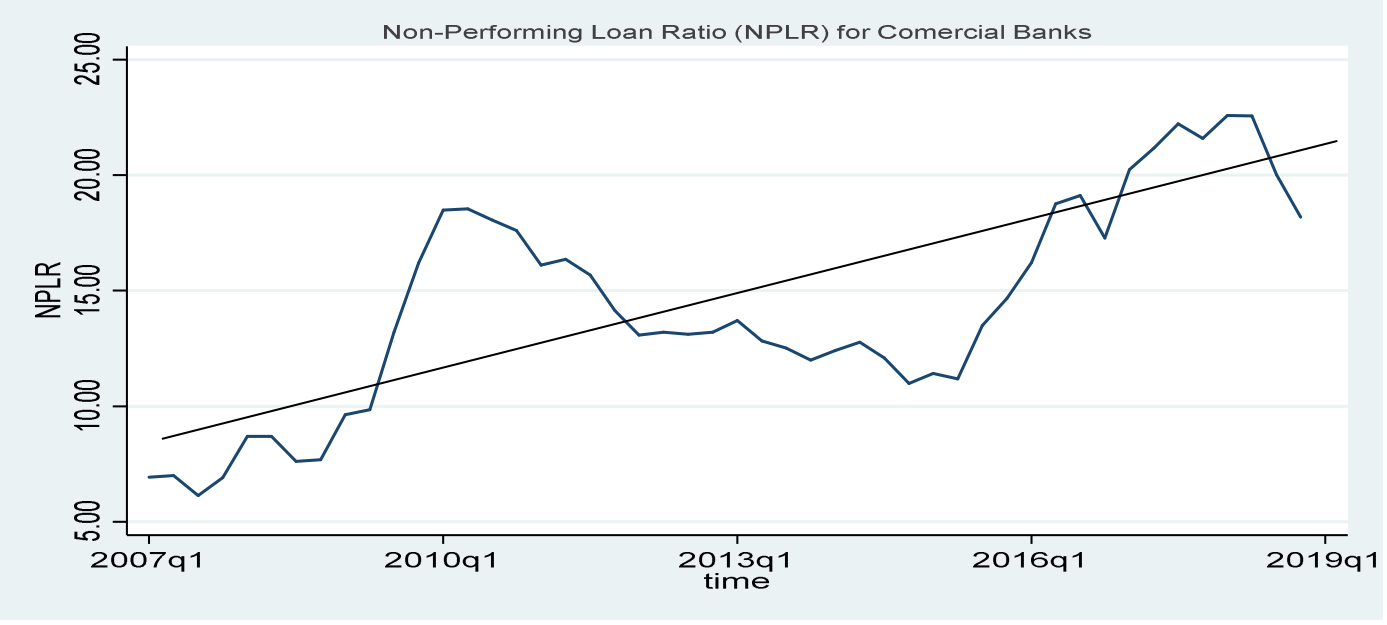

Figure 4.1: Trend of NPLs

Source: Researchers construct, 2020 (Financial Soundness Indicators 2007 - 2018)

4.2 Diagnostic and Reliability Test

The Variance Inflation Factor (VIF) of the independent variables further assesses the issue of multicollinearity. A VIF index greater than 5, is indicative of a high degree of multicollinearity among the variables. From Table 4.2, the independent variables used in the study have VIF values lower than 5, indicating that there is no issue of multicollinearity among the variables. From Table 4.2, all the independent variables have weak to moderate correlation coefficients.

Table 4.2: Variance Inflation Factors (VIF)

\begin{tabular}{lcc}
\hline Variable & VIF & 1/VIF \\
\hline IFR & 1.76 & 0.568067 \\
IR & 1.61 & 0.620011 \\
NPLR & 1.12 & 0.891845 \\
CAR & 1.1 & 0.905842 \\
LR & 1.08 & 0.922162 \\
\hline Mean VIF & 1.34 & \\
\hline
\end{tabular}

Source: Researchers construct, 2020 (Financial Soundness Indicators 2007 - 2018)

To carry out a meaningful regression on the time series data, there is the need to test it for stationarity. The presence of unit roots leads to wrong inferences and ultimately wrong conclusions. The study employs the 
Augmented Dickey-Fuller (ADF) to test the stationarity of the data and present the findings in Table 4.3. The results of the unit root test show that ROA, ROA, ROE, NPLR, IR, IR and IFR are all stationary at first deference and significant at various p-values. The results indicate that all the variables are integrated of order $1(1)$ which implies that they are non-stationary at level. The ADF test statistics were greater than the critical values at $5 \%$ showing the variables were stationary at $1(1)$.

Table 4.3: Unit Root Test (ADF)

\begin{tabular}{lccccc}
\hline Variable & Test Statistic & $\mathbf{5 \%}$ Critical Value & P-value & Order of Integration & Decision \\
\hline ROE & -10.965 & -3.516 & 0.0000 & $1(0)$ & Stationary \\
ROA & -9.762 & -3.516 & 0.0000 & $1(0)$ & Stationary \\
NPLR & -4.42 & -3.516 & 0.0020 & $1(0)$ & Stationary \\
CAR & -6.744 & -3.516 & 0.0000 & $1(0)$ & Stationary \\
LR & -8.983 & -3.516 & 0.0000 & $1(0)$ & Stationary \\
IR & -3.817 & -3.516 & 0.0157 & $1(0)$ & Stationary \\
IFR & -4.318 & -3.516 & 0.0029 & $1(0)$ & Stationary \\
\hline
\end{tabular}

Source: Researchers construct, 2020 (Financial Soundness Indicators 2007 - 2018)

\subsection{Correlation Analysis}

The correlations between pairs of independent and control variables are within the acceptable threshold. The findings in Table 4.4, reveal that the independent variables used in the study are not highly correlated. The highest observed positive correlation between capital adequacy ratio (CAR) and the non-performing loan ratio (NPLR) is 0.67. Also, -0.47 is the highest negative correlation between capital adequacy ratio (CAR) and inflation rate (IFR). In line with Greene (2008), the threshold for this test is 0.8 or -0.8 and notably, all the correlation coefficients of the independent and control variables are within the threshold -0.8 to 0.8 . This concludes that the independent variables do not suffer severe multicollinearity and not pose a problem to the model findings and subsequent inferences.

The correlations analysis in Table 4.4 is conducted to examine the strength of the relationship between the dependent variables (ROE, ROA) and independent variables (NPLR, CAR, LR, IR, IFR). NPLR is negatively correlated with ROE. The relationship between the two variables is moderately strong with a correlation coefficient of - 0.59 . This indicates that a decrease in non-performing loans ratio (NPLR) increases ROE. Likewise, a rise in the number of non-performing loans has a negative effect on profitability. In line with the findings, Mwangi (2012), finds an opposite correlation between non-performing loans and the financial results of banks. Eston, Willy and Agnes (2016) reveal that an increase in non-performing loans has a negative effect on the profitability of banks. The study reveals that non-perform loans ratio (NPLR) is negatively associated with return on asset (ROA). This indicates that a reduction in non-performing loans increases the return on asset of universal banks. Also, when non-performing loans go up, profitability (ROA) of universal banks reduces.

Table 4.4 Correlation Matrix of Dependent and Independent Variables

\begin{tabular}{lccccccc}
\hline & ROE & NPLR & CAR & LR & IR & IFR & ROA \\
\hline ROE & 1 & & & & & & \\
NPLR & -0.5942 & 1 & & & & & \\
CAR & 0.2354 & 0.672 & 1 & & & & \\
LR & -0.2135 & 0.3194 & 0.132 & 1 & & & \\
IR & 0.0157 & 0.344 & 0.0005 & 0.4043 & 1 & & \\
IFR & 0.2674 & -0.2925 & -0.4783 & 0.1316 & 0.6566 & 1 & \\
ROA & 0.8491 & -0.1879 & 0.0977 & -0.0432 & 0.2895 & 0.2138 & 1 \\
\hline
\end{tabular}

Source: Researchers construct, 2020 (Financial Soundness Indicators 2007 - 2018)

\subsection{Regression Analysis}

Table 4.5 presents the results of a regression analysis of the independent on the dependent variable after the time series data has been tested for both multicollinearity and unit root to ensure they are fit for regression analysis. The study reveals that $63 \%$ of the movement in the profitability (ROE) of universal banks has been collectively explained by the independent variables (non-performing loans ratio, capital adequacy ratio, liquidity ratio, interest rate, inflation rate). Table 4.5 reveals that, non-performing loans ratio has a statistically significant negative relationship with return on equity (ROE). This indicates that NPLs have a significant negative effect on profitability (ROE) of universal banks in Ghana. A unit increase in non-performing loans ratio leads to a corresponding decrease in return on equity by 1.149 . The finding is consistent with the findings of other researchers who establish that NPLs affect the profitability of universal banks negatively (Chege and Bichanga, 2016; Islam \& Nishiyam, 2019, Okoh, Inim \& Idachaba, 2019). 
Table 4.5: Regression Analysis of the ROE model

\begin{tabular}{llccc}
\hline ROE & Coef. & Std. Err. & t & P>t \\
\hline NPLR & -1.41912 & 0.193588 & -7.33 & 0.001 \\
CAR & 0.991996 & 0.400662 & 2.48 & 0.017 \\
LR & -0.21541 & 0.248809 & -0.87 & 0.392 \\
IR & -0.0219 & 0.326993 & -0.07 & 0.947 \\
IFR & 0.137733 & 0.289247 & 0.48 & 0.636 \\
cons & $8.64 \mathrm{E}-09$ & 0.477516 & 0 & 1.000 \\
\hline Number of obs & 48 & & R-squared & 0.6330 \\
F $(5$, 42) & 14.49 & Adj R-squared & 0.5893 \\
Prob $>$ F & 0.0000 & Root MSE & 3.3083 \\
\hline
\end{tabular}

Source: Researchers construct, 2020 (Financial Soundness Indicators 2007 - 2018)

Table 4.6 captures the regression analysis of return on asset (ROA) model. The regression model results show that $53.5 \%$ of the profitability of universal banks in Ghana can be explained by the independent variables. The results also indicate that $46.4 \%$ variations in the profitability of universal banks are explained by other factors not included in the model.

From the study results, non-performing loan has a significant negative effect on profitability (ROA) of universal banks $(\mathrm{p}$-value $=0.000)$. The regression shows a statistically significant negative relationship between NPLs and profitability of universal banks in the Ghanaian banking industry. The finding indicates that an increase in non-performing loan ratio by one unit will lead to a corresponding 0.279 reduction in return on asset of universal banks. Consistent with the findings, other researchers have established a negative effect of non-performing loan on the profitability of banks (Afriyie \& Akotey, 2013; Arko, 2012; Mwangi, 2014; Baasi, 2018; Linh-Doa, XuanNgoa, \& Anh-Phunga,2020). Eston, Willy and Agnes (2016) find that profitability has an inverse relationship with NPLs and has a negative effect on the growth of the banking industry which is consistent with the findings of the study.

Table 4.6: Regression Analysis of the ROA model

\begin{tabular}{llccc}
\hline ROA & Coef. & Std. Err. & t & P>t \\
\hline NPLR & -0.27909 & 0.045103 & -6.19 & 0.000 \\
CAR & 0.313823 & 0.093349 & 3.36 & 0.002 \\
LR & -0.04734 & 0.057969 & -0.82 & 0.419 \\
IR & 0.045424 & 0.076185 & 0.6 & 0.554 \\
IFR & 0.011033 & 0.06739 & 0.16 & 0.871 \\
cons & $4.82 \mathrm{E}-09$ & 0.111255 & 0.00 & 1.000 \\
\hline Number of obs & 48 & & R-squared & 0.5354 \\
F $(5,42)$ & 9.68 & Adj R-squared & 0.4801 \\
Prob $>$ F & 0.0000 & Root MSE & 0.77079 \\
\hline
\end{tabular}

Source: Researchers construct, 2020 (Financial Soundness Indicators 2007 - 2018)

\section{Conclusion}

The study reveals non-performing loans have a significant negative relationship with return on equity. An increase in non-performing loans ratio results in a decline in return on equity of universal banks by $140 \%$. The study also finds a negative relationship between non-performing loan ratio and return on asset of universal banks. The relationship between non-performing loans of universal banks and their return on asset is significant at a $5 \%$ confidence level. An increase in non-performing loans of universal banks reduces profit (return on asset) by $27 \%$. The study concludes that non-performing loans have a significant negative effect on return on equity of universal banks in Ghana. The effect of non-performing loans indicates that the ability of universal banks to generate enough return on investment is curtailed in the Ghanaian banking industry as a result of increasing non-performing loans. This means that it is important to reduce non-performing loans to improve return on equity. Also, the significant negative relationship between non-performing loans ratio and return on asset shows that non-performing loans negatively affect return on asset of universal banks in Ghana. Non-performing loans affect the ability of universal banks to utilise their assets more efficiently for-profit generation. The study concludes that non-performing loans contribute to the slow growth in asset. This contributes to the underperformance in the use of bank assets to generate enough revenue to both make the bank profitable and also improve the wealth of shareholders.

The study recommends an improvement in the profitability of universal banks by reducing non-performing loans in individual banks. Universal banks must improve their loan monitoring strategies and also effectively manage their loan risk exposure to their customers. The banks should ensure that loans that are giving to clients are constantly monitored by credit officers to assess their risk exposure on the loans while they develop exit strategies to ensure they limit the amount of non-performing loans on their books. Banks also identify innovative strategies to mitigate how non-performing loans affect their bottom-line. The banks should seek to insure loans 
against default from customers to reduce the effect it has on their profit if customers do not pay their loans. Universal banks should extend credit protection (insurance) to all forms of loans in order to claim from insurance companies, debt against default, insolvency and bankruptcy of customers. Subsequently, the negative effect of non-performing loans on the banking industry shows the regulatory system of the central bank needs to improve. The study recommends instituting appropriate guidelines by the Bank of Ghana which will prevent universal banks from advancing loans to customers that have a high credit risk.

\section{References}

Abdullahi S. R. (2013). Efficacy of Credit Risk Management on the Performance of Banks in Nigeria. A Study of Union Bank PLC (2006-2010). Global Journal of Management and Business Research Administration and Management, 1(13), $621-651$.

Abend, G. (2013). The Meaninfg of Theory. (S. Richard, Ed.) Sociological Theory, 173-199.

Abiola, I., \& Olausi, A.S. (2014). The Impact of Credit Risk Management on the Commercial Banks Performance in Nigeria. International Journal of Management and Sustainability, 3(5), 295-306.

Afriyie, H. O. \& Akotey, J. O. (2013). Credit Risk Management and Profitability of Rural Banks in the BrongAhafo Region. European Journal of Business and Management 5(4), 24-33

Alshatti A. S. (2015). The effect of credit risk management on financial performance of the Jordanian commercial banks. Investment Management and Financial Innovations, 12 (1), 338 - 345

Arko, S.K. (2012). Determining the causes and impact of nonperforming loans on the operations of microfinance institutions: A case of Sinapi Aba Trust. Unpublished Executive MBA Thesis. KNUST.

Asantey J. O. \& Tengey S. (2014). An Empirical Study on the Effect of Bad Loans on Banks' Lending Potential and Financial Performance: The Case of SMEs Lending in Ghana. International Journal of Research in Business Management, 2(11), 38-47.

Awoyemi, S. O. (2014). The Impact of Credit Risk Management on The Commercial Banks Performance in Nigeria. Conscientia Beam, 3(5), 295-306.

Baasi, M.N. (2018). Effects of Non-Performing Loans on the Profitability of Commercial Banks - A Study of Some Selected Banks on the Ghana Stock Exchange. Global Journal of Management and Business Research,18(1), 2249-4588.

Bank of Ghana (2018). Government Establishes New Indigenous Bank; Bank of Ghana Revokes Licences of Five Banks and appoints receiver in respect of their assets and liabilities. Bank of Ghana press.

Barseghyan, L. (2010). Non-performing loans, prospective bailouts, and Japan's slowdown. Journal of Monetary Economics, 57(7), 873-890.

Basel Committee on Banking Supervision (2001). Principles for the Management of Credit Risk. CH-4002 Basel, Switzerland Bank for International Settlements.

Bawumia, M. (2010). Monetary Policy and Financial Sector Reform in Africa: Ghana's Experience, Combert Impressions Ghana Ltd., Ghana.

Beck, R., Jakubik, P., \&Piloiu, A. (2013). Non-performing loans: What matters in addition to the economic cycle? European Central Bank Working Paper Series, no 1515.

Betz, J., Krüger, S., Kellner, R., \& Rösch, D. (2017). Macroeconomic effects and frailties in the resolution of nonperforming loans. Journal of Banking \& Finance, 221, 6-68. doi:10.1016/j.jbankfin.2017.09.008

Bloem, M. A. and Gorter, N. C. (2011). Treatment of Non-Performing Loans in Macroeconomic Statistics. IMF Working Paper, WP/01/209.

Boahene, S. H., Dasah, J. and Agyei, S. K. (2012). Credit Risk Management and profitability of some selected banks in Ghana. Research Journal of finance and accounting, 3(7), 6-14.

Bofondi, M., \& Ropele, T. (2011). Macroeconomic determinants of bad loans: evidence from Italian banks. Questioni di Economia e Finanza (Occasional Papers), No 89. Bank of Italy.

Chege, L.M and Bichanga, J. (2016). Non-Performing Loans and Financial Performance of Banks: Am empirical Study of Commercial Banks in Kenya. International Journal of Management and Commerce Innovations, 4, 909-916

Chimkono, E.E., \& Muturi, W. and Njeru, A. (2016). Effect of Non-Performing Loans and Other Factors On Performance of Commercial Banks in Malawi. International Journal of Economics, Commerce and Management, 9 (2), 549- 569

Creswell, J. W. (2012). Educational research: Planning conducting evaluating quantitative and qualitative research (4thed.). Upper Saddle River, NJ: Merill.

Creswell, J., \& Poth, C. N. (2017). Qualitative inquiry and research design; Choosing among five approaches, second edition. The Journal of Pediatrics. https://doi.org/10.1016/S0022-3476(89)80781-4

Curak, M., Pepur, S., \& Poposki, K. (2013). Determinants of Non-Performing Loan; Evidence from Southeastern European Banking System. Banks and Banking Systems.8(3), 45-53

Durafe, A., \& Singh, M. (2016). Cyclical Behaviour of Public and Private Sector Banks: A Comparative Study of 
Non-Performing Assets. Journal of Business and Management Research, 1(1), 14-25.

Ekanayake, E. M. N. N., \& Azeez, A. A. (2015). Determinants of Non-Performing Loans in Licensed Commercial Banks: Evidence from Sri Lanka. Asian Economic and Financial Review, 5(6), 868.

Enders, W. (2004). Applied Econometric Time Series (2nd ed), John Wiley \& Sons Inc, New York.

Engle, R. F., \& Granger, C. W. J. (1987). Co-Integration and Error Correction: Representation, Estimation and Testing. Econometrica, 55(2), $251-276$.

Epure, M. and Lafuente, I. (2012). Monitoring Bank Performance in the Presence of Risk, Barcelona GSE Working Paper Series No.61.

Eston, E. C, Willy, M \& Agnes, N. (2016). Effect of Non-Performing Loans and Other Factors on Performance of Commercial Banks in Malawi. International Journal of Economics, Commerce and Management United Kingdom, 9 (2), 549 -563.

Farhan, M., Sattar, A., Chaudhry, A. H., \& Khalil, F. (2012). Economic Determinants of Non-Performing Loans: Perception of Pakistani Bankers. European journal of business and Management, 4(19), 87-99.

Galvao, A. F., Montes-Rojas, G., Sosa-Escudero, W., \& Wang, L. (2013). Tests for skewness and kurtosis in the one-way error component model. Journal of Multivariate Analysis, 122, 35-52.

Greenidge, K. and Grosvenor, T. (2010). Forecasting non-performing loans in Barbados. Journal of Business, Finance and Economics in Emerging Economies, 5, 80-107

Guy, K. (2011). Non-performing loans. The Central Bank of Barbados Economic Review,37(1), 10-12.

Haneef, S., Riaz, T., Ramzan, M., Rana, M. A., Ishaq, H. M., \& Karim, Y. (2012). Impact of risk management on non-performing loans and profitability of banking sector of Pakistan. International Journal of Business and Social Science, 3(7), 308-315.

Ikram, A., Su, Q., \& Sadiq, M. A. (2016). Technical Efficiency and Its Determinants: An Empirical Study of Surgical Instruments Cluster Of Pakistan. Journal of Applied Business Research (JABR), 32(2), 647. doi.org/10.19030/jabr.v32i2.960

Islam, M.S., \& Nishiyama, S.I. (2019). Non-Performing Loans of Commercial Banks in South Asian Countries: Adverse Selection and Moral Hazard Issues. Asian Economic and Financial Review, 9 (9), 1091-1106.

Jimenez, G., \& Saurina, J. (2015). Credit cycles, credit risk, and prudential regulation. Banco de Espana Working Paper.

Johansen, S., \& Juselius, K. (1990). The full information maximum likelihood procedure for inference on cointegration-with applications to the demand for money. Oxford Bulletin of Economics and Statistics, 52(2), 169-211

Joseph, M.T., Edson, G., Manuere, F., Clifford, M., and Michael, K. (2012). Non-Performing Loans in Commercial Banks: A Case of CBZ Bank Limited 27 In Zimbabwe. Interdisciplinary Journal of Contemporary Research in Business, 4 (7), 221 - 254.

Kamran, H. W., Malik, S., Hamas Butt, M. H., Afzal, U., \& Maqbool, S. (2016). Risk Premium and Its Effect on Bank's Non-Performing Loans. International Journal of Innovation and Economic Developmen, 1(6), 79-89.

Kargi, H. S. (2011). Credit risk and the performance of Nigerian banks. Unpublished MBA Theis, Bello University, Zaria - Nigeria

Karim, M. Z. A., Chan S. G, \& Hassan, S. (2010). Bank Efficiency and Non-Performing Loans: Evidence from Malaysia and Singapore. Prague Economic Papers, 2, 118-132.

Khalid A. (2012). The impact of Asset Quality on Profitability of Private Banks in India: A Case Study of JK, ICICI, HDFC \& YES Banks. Journal of African Macroeconomic Review, 2(1), 1-15

Khemraj, T. \& Pasha, S. (2012). The Determinants of Non-Performing Loans: An Econometric case study Guyana. Savez ekonomista Vojvodine, Novi Sad, Serbia, 61(2), 193-206,

Kipyego, D. K., \& Wandera, M. (2013). Effects of Credit Information Sharing on Non-Performing Loans. European Scientific Journal, 9(13), 1857-1860

Kipyego, D. K., and Wandera, M. (2013). Effects of Credit Information Shairng on Non-Performing Loans. European Scientific Journal, 9(13), 1857-1860

Kithinji, A.M. (2010). Credit Risk Management and Profitability of Commercial Banks in Kenya, School of Business, University of Nairobi, Nairobi. Journal of Research in Commerce and Management, 1(1): 37-44

Kjosevski, J., Petkovski, M., \& Naumovska, E. (2019). Bank-specific and macroeconomic determinants of nonperforming loans in the Republic of Macedonia: Comparative analysis of enterprise and household NPLs. Economic Research-Ekonomska Istraživanja, 32(1), 1185-1203. doi:10.1080/1331677x.2019.1627894

Klein, N. (2013). Non-performing loans in CESEE: Determinants and impact on macroeconomic performance. IMF Working Paper, WP/13/72, 1-26.

Kolapo, T.F., Ayeni, R.K and Oke, M.O (2012). Credit risk and Commercial Banks' Performance in Nigeria. Australian Journal of Business and Management Research, 2(2), 31-38.

Kwambai, K. D., W \& Era, M. (2013). Effects of credit information sharing on nonperforming Loans: The case of Kenya commercial banks. European Scientific Journal, 9 (13), 221-225. 
Linh-Doa, H., Xuan-Ngoa, T., \& Anh-Phunga, O. (2020). The effects of non-performing loans on profitability of commercial banks: Case of Vietnam. Growing Science Journal of Accounting, 6 (1), 373-386.

Louzis, D. P., Vouldis, A. T., \& Metaxas, V. L. (2010). Macroeconomic and bank-specific determinants of nonperforming loans in Greece: a comparative study of mortgage, business and consumer loan portfolios. Journal of Banking \& Finance, 36, 1012-1027.

Marshal, I., \& Onyekachi, O. (2014). Credit Risk and Performance of Selected Deposit Money Banks in Nigeria: An Empirical Investigation. European Journal of Humanities and Social Sciences Vol, 31(1).

McMillan, J., \& Schumacher, S. (2014). Research in Education: Evidence-Based Inquiry. In Pearson.

Mills, E. F.E. and Amowine, N. (2013). Rural Bank Profitability Nexus; Evidence from Ghana" International Journal of Application or Innovation in Engineering and Management, 2(1), 506-513.

Mohammed, F. (2012) Impact of Corporate Governance on Banks Performance in Nigeria. Journal of Emerging Trends in Economics and Management Sciences (JETEMS) 3(3),257-260

Mugenda, O.M. and Mugenda, A.G. (2003) Research Methods, Quantitative and Qualitative Approaches. ACT, Nairobi.

Mwengei, K.B.O. (2013). Assessing the factors contributing to non-performing loans in Kenyan banks. European Journal of Business Management, 5(32), 155-163.

Ng'etich, J.C. \& Wanjau, K. (2016). The effects of interest rate spread on the level of non-performing assets: A case of commercial banks in Kenya. International Journal of Business and Public Management, 1(1), 58-65.

Ng'etich, J.C. and Wanjau, K. (2011). The effects of interest rate spread on the level of non-performing assets: A case of commercial banks in Kenya. International Journal of Business and Public Management, 1(1), 58-65.

Nir K. (2013) Non-Performing Loans in CESEE: Determinants and Macroeconomic Performance. IMF Working Paper

Njeri, H., Olweny, T., \& Opuodho, G. (2018). The Effect of Non-Performing Loans Management Practices on the Financial Performance of Commercial Banks in Kenya. International Journal of Social Sciences and Information Technology, 9 (10), 478 - 491.

Nyarko, B. M. (2018). Effects of Non-Performing Loans on the Profitability of Commercial Banks - A Study of Some Selected Banks on the Ghana Stock Exchange. Global Journals, 18 (2), 2249-4588. doi:10.1080/1331677x.2019.1627894

Ogboi, C., \&Unuafe, O. K. (2013). Impact of credit risk management and capital adequacy on the financial performance of commercial banks in Nigeria. Journal of Emerging Issues in Economics, Finance and Banking,2(3), 703-717.

Okoh, G., Inim, E.K., \& Idachaba, O.I. (2019). Effect of Non-Performing Loans on the Financial Performance of Commercial Banks in Nigeria. American International Journal of Business and Management Studies, 1 (2), $1-9$.

Onaolapo, A. R. (2012). Analysis Of Credit Risk Management Efficiency in Nigeria Commercial Banking Sector, (2004-2009). Far East Journal of Marketing and Management, 2(4), 39-52.

Ongore, V. O. and Kusa, G. B. (2013). Determinants of Financial Performance of Commercial Banks in Kenya. International Journal of Economics \\& Financial Issues (IJEFI), 3 (1), 445-515.

Partovi, E., \& Matousek, R. (2018). Bank Efficiency and Non-Performing Loans: Evidence from Turkey. Research in International Business and Finance. 48, 287-309. doi:10.1016/j.ribaf.2018.12.011

Pesaran, M. H., Shin, Y., \& Smith, R. J. (2001). Bounds Testing Approaches to the Analysis of Level Relationships. Journal of Applied Econometrics, 16(3), 289-326.

Pollio, G. \& Obuobi, J. (2010), Microfinance Default Rate in Ghana: Evidence from Individual Liability credit contract.

Pop, I. D., Cepoi, C. O., \& Anghel, D. G. (2018). Liquidity-threshold effect in non-performing loans. Finance Research Letters, 7, 124-128. doi:10.1016/j.frl.2018.02.012

Poudel, R. P. S. (2012). The impact of credit risk management on financial performance of commercial banks in Nepal. International Journal of arts and commerce, 1(5), 9-15.

PricewaterhouseCoopers (2011) Ghana Banking Survey 2011, Sustaining Growth: Challenges and Opportunities, http://www.pwc.com/en_gh/gh/pdf/ghana-banking-survey-2011.pdf

PwC. (2019). Banking reforms so far: topmost issues on the minds of bank CEOs. Ghana Banking Survey

Rawlin, R., Shwetha, M. M., \& Sharan and Pradeep, B. L. (2012). Modelling the NPA of Midsized Indian Nationalized Bank as Function of Advances. European Journal of Business and Management, 4(5), 12-20.

Richard, E. (2011). Factors that cause non-performing loans in commercial banks in Tanzania and strategies to resolve them. Journal of Management Policy and Practice, 12(7), 50-58

Richard, E. (2016). Factors that cause non-performing loans in commercial banks in Tanzania and strategies to resolve them. Journal of Management Policy and Practice, 12(7), 50-58.

Roberto A. De Santis and Paolo S. (2013) Bank Lending and Monetary Transmission in the Euro Area, Working Paper Series No. 1568 of the European Central Bank (ECB) 
Rose, S.P, and Hudgins, S.C (2008). Bank management and financial services; edition seventh. Published by McGraw Hill Education

Saunders, M., Lewis, P. \& Thornhill, A. (2010). Research methods for business students (5th ed.). Harlow, Essex: Pearson Education Limited.

Sobarsyah, M., Soedarmono, W., Yudhi, W. S. A., Trinugroho, I., Warokka, A., \& Pramono, S. E. (2020). Loan growth, capitalization and credit risk in Islamic banking. International Economics, 163, 155-162 doi:10.1016/j.inteco.2020.02.001

Studenmund, A. H. (2011). Using econometrics: a practical guide. (6th ed). Boston, Massachusetts: Pearson.

Subaru G, Nafiu A and Omankhanlen O, (2011). CBN Grants New Licenses to 17 Banks, Nigerian Tribune Newspaper, June 1, pp 53.

Talata, N. (2015). The Effect of Non-Performing Loans on The Financial Performance of Selected Rural Banks in The Western and Ashanti Regions of Ghana. Unpublished MBA thesis, KNUST

Vithessonthi, C. (2016). Deflation, bank credit growth, and non-performing loans: Evidence from Japan. International Review of Financial Analysis, 45, 295-305. doi: 10.1016/j.irfa.2016.04.003

Yurttadur, M., Celiktas, E., \& Celiktas, E. (2019). The Place of Non-Performing Loans in the Turkish Banking Sector. Procedia Computer Science, 158, 766-771. doi: 10.1016/j.procs.2019.09.113 